\title{
British Journal for the History of Philosophy
}

\section{Wittgenstein's influence on Austin's philosophy of language}

\section{Daniel W. Harris \& Elmar Unnsteinsson}

To cite this article: Daniel W. Harris \& Elmar Unnsteinsson (2018) Wittgenstein's influence on Austin's philosophy of language, British Journal for the History of Philosophy, 26:2, 371-395, DOI: 10.1080/09608788.2017.1396958

To link to this article: https://doi.org/10.1080/09608788.2017.1396958

\section{册Published online: 05 Dec 2017.}

Submit your article to this journal $\pi$

Цll Article views: 69

Q View related articles $₫$

View Crossmark data $\nearrow$ 


\title{
Wittgenstein's influence on Austin's philosophy of language
}

\author{
Daniel W. Harris (1) ${ }^{\mathrm{a}}$ and Elmar Unnsteinsson (10 ${ }^{\mathrm{b}}$

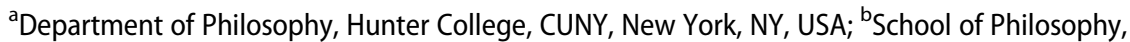 \\ University College Dublin, Dublin 4, Ireland
}

\begin{abstract}
Many philosophers have assumed, without argument, that Wittgenstein influenced Austin. More often, however, this is vehemently denied, especially by those who knew Austin personally. We compile and assess the currently available evidence for Wittgenstein's influence on Austin's philosophy of language. Surprisingly, this has not been done before in any detail. On the basis of both textual and circumstantial evidence we show that Austin's work demonstrates substantial engagement with Wittgenstein's later philosophy. In particular, Austin's 1940 paper, 'The Meaning of a Word', should be construed as a direct response to and development of ideas he encountered in Wittgenstein's Blue Book. Moreover, we argue that Austin's mature speech-act theory in How to Do Things with Words was also significantly influenced by Wittgenstein.
\end{abstract}

ARTICLE HISTORY Received 10 January 2017; Revised 3 July and 21 October 2017; Accepted 23 October 2017

KEYWORDS Wittgenstein; speech-act theory; philosophy of language; Austin; ordinary language philosophy

I should not like my writing to spare other people the trouble of thinking. But if possible, to stimulate someone to thoughts of his own.

(Ludwig Wittgenstein, 1945 Preface to Philosophical Investigations)

Let's see what Witters has to say about that.

(J. L. Austin, 1955, as recounted by George Pitcher ('Austin', 24))

\section{Introduction}

Wittgenstein and Austin are often grouped together in the history of analytic philosophy. This is understandable: Austin's career coincided Wittgenstein's second act, and during this time, they both developed approaches to philosophy that criticized the positivist tradition by carefully emphasizing the ways

CONTACT Elmar Unnsteinsson elmar.geir@gmail.com

We use the following abbreviations for titles in this article: ' $\mathrm{Pl}$ ' = Philosophical Investigations, 'MW' = 'The Meaning of a Word', 'BB' = The Blue Book, 'HTW' = How to Do Things with Words.

(c) 2017 BSHP 
in which natural language actually works. They are thus often imagined as the two principal wellsprings - located only eighty miles apart - from which flowed a naturalistic, usage-focused tradition in post-positivist philosophy of language.

This popular image raises the question of influence. In particular, since Wittgenstein seems to have had no appreciation for Austin: ${ }^{1}$ to what extent was Austin's philosophy of language the product of engagement with Wittgenstein's work? This is a surprisingly difficult question to answer, and there has been no detailed attempt to answer it to date. What literature does exist on this issue falls into two opposing strands, both of which are unsatisfactory.

The first of these strands consists of widespread claims that Wittgenstein's later work was a major influence on Austin and his colleagues at postwar Oxford. This passage from Hans-Johann Glock's 2008 monograph, What is Analytic Philosophy?, gives a typical example of such claims: ${ }^{2}$

Wittgenstein's new ideas, combined with Moore's common-sense philosophy, had a profound impact on a movement which emerged around the turn of the 1930s and dominated British philosophy until the 1960s. Its opponents called it 'ordinary language' or 'Oxford philosophy', since its most eminent proponents - Ryle, Austin and Strawson - were based there.

(Glock, What Is Analytic Philosophy?, 42)

We have found that claims of this sort typically are not accompanied by evidence of any kind, however, and so they tend to come off as worryingly sweeping and speculative. Part of our goal here is to assess them in some detail.

The second school of thought is what we like to call 'Oxonian originalism', both because it centres around the claim that Wittgenstein did not influence Austin - and thus that Austin's views and methodology are largely original to Oxford - and because the view's proponents are mainly Austin's colleagues or students from Oxford. Particularly clear specimens of Oxonian originalism can be found, in several places, in the blustery voice of John Searle, who was in Oxford from 1952 until he received his D.Phil. in 1959:

I often read how much Austin was influenced by Wittgenstein. Nothing could be further from the truth. Austin had no sympathy whatever for Wittgenstein, and I think he was incapable of learning from someone whose style was so 'loose'. He

\footnotetext{
${ }^{1}$ Wittgenstein and Austin were together in the same room at least once, on 31 October 1946, when Austin gave a paper called 'Nondescription' at the Moral Sciences Club. The meeting's minutes show that Wittgenstein chaired. In a letter to G. E. Moore a few weeks later, following another paper at the Club by $\mathrm{H}$. H. Price, Wittgenstein says that 'Price at the last Mor. Sc. Cl. meeting was by far better than Austin had been' (McGuinness, Wittgenstein in Cambridge, 405). This letter is the only solid evidence we have of what Wittgenstein thought about Austin's work, and it suggests that he thought very little of it, in both senses of the phrase.

${ }^{2}$ In a similar vein, Ernest Gellner writes that Ryle and Austin 'of course shared and emulated Wittgenstein's linguistic naturalism and the method based on it' (Words and Things, 23). And Gary Kemp claims that both the Investigations and The Blue and Brown Books 'played a decisive role in the rise of so-called "ordinary language" philosophy, which reached its peak in the 1950s and 1960s' (What Is This Thing Called Philosophy of Language?, 101).
} 
typically referred to Wittgenstein in the style of English schoolboy slang of the time as, 'Witters', pronounced 'Vitters'. He thought there were no original ideas in Wittgenstein. Indeed he once said to me about Wittgenstein's philosophy, 'It's all in Moore', one of the least accurate things I have ever heard Austin say. If Austin had an inspirational model, it was Moore. ${ }^{3}$

(Searle, 'J. L. Austin', 227)

Similarly, here is Geoffrey Warnock, who was Austin's colleague at Oxford from 1949: 4

... he did not join at any time in the general deference to Wittgenstein. The personal atmosphere surrounding Wittgenstein's work strongly repelled him; and it is of course crucial also that Wittgenstein rejected, deliberately and on principle, exactly that ideal of finality, of definite, clearly and fully stated solutions, which Austin regarded as alone worth seriously striving for. That Wittgenstein influenced his views has been sometimes suggested, but is certainly untrue.

(Warnock, 'John Langshaw Austin, a Biographical Sketch', 11)

The originalists can all be interpreted as putting forward an argument that goes something like this: Austin found Wittgenstein's style and personality distasteful, and thought that Wittgenstein's conclusions and philosophical method were irresponsible and loose; therefore, Austin was not influenced by Wittgenstein. ${ }^{5}$ But the enthymematic premise of this argument equates philosophical influence with the gathering of disciples. This is a false and deeply misleading assumption.

In fact, we would go so far as to argue that a paradigmatic form of philosophical influence - and perhaps the most philosophically interesting and fruitful form of influence - takes a very different form. The dynamic we have in mind occurs when a younger philosopher reacts to the work of an

\footnotetext{
${ }^{3}$ Similarly, Grice (Studies in the Way of Words, 381) quotes Austin as saying 'Some like Witters, but Moore is my man'.

${ }^{4} \mathrm{As}$ both of these passages suggest, Oxonian originalism is often premised on the fact that Austin seems to have had disdain for Wittgenstein - both for his philosophical style, and for aspects of his personality and position in postwar philosophy. Some originalists shared this view themselves. Perhaps the most biting illustration of such disdain can be found in a letter written by Isaiah Berlin, dated 9 May 1951, only a week or so after Wittgenstein's death:
}

The Wittgenstein intimates - Miss Anscombe, her husband Geach, and others - were thinking of founding a colony in order to live, think, eat and be like Ludwig. Originally it was intended to invite L. himself, but now that he is dead they propose to establish it anyhow. A great deal of violent artificial neurosis, not washing etc., anyhow you can imagine - hideous stammering in place of articulate speech, perverted Catholicism and all the other delicious attributes.

(Berlin, Enlightening, 229)

${ }^{5}$ Mathieu Marion provides an even more explicit example of this kind of argument:

One frequent but incorrect assumption is that the later Wittgenstein influenced Austin. The fact that there was no real influence was noted by all who knew him well, for example by Ryle who pointed out that 'Austin took as little as he could after Wittgenstein, a lot after Moore'. As a matter of fact, Austin and Wittgenstein disliked each other. 
older philosopher by recognizing the importance of their questions, but comes to believe that they can provide better answers to those questions by means of better methods. This is a process by which many important and influential philosophers - as opposed to acolytes and hangers on - are influenced by their predecessors.

This sort of influence need not always be direct, consciously acknowledged, or accompanied by reverence for the influencer. In some cases, the influencer succeeds in establishing certain questions as the dominant ones of the era, and they come to preoccupy the younger philosopher as a result. In principle, this could happen entirely via intermediaries, without the younger philosopher ever reading or interacting with the older philosopher. Partly for this reason, and partly because it is possible to forget or otherwise fail to recognize the source of an idea's inspiration, a philosopher need not consciously recognize even major sources of influence. And even when the source of inspiration for one's ideas are (or should be) clear, there are powerful incentives to repress or deny the notion that influence has taken place, and even to express disdain for the influencer, thereby protecting one's claim to originality. ${ }^{6}$ Russell's and Moore's influence on Wittgenstein himself could, some would argue, be described in similar terms.

It is compatible with our argument here that Wittgenstein's influence on Austin was, at least in part, indirect and either unconscious to or repressed by Austin. Certainly, by the time of Austin's mature work on speech acts, Wittgenstein's ideas hung thick in the air. Gilbert Ryle and John Wisdom are among the most obvious indirect vectors by which Wittgenstein's views would have reached Austin, and we will discuss both below. And although we have found no evidence of Austin himself denying, directly, that he was influenced by Wittgenstein, some of those who knew him have done so, and provided evidence that suggests Austin held Wittgenstein in disdain.

However, we are convinced that at least some of Wittgenstein's influence was direct and consciously acknowledged by Austin. Our evidence will come from careful readings of two texts. In Section 2, we will show that Austin's essay, 'The Meaning of a Word' ('MW'), which was originally presented in 1940 but first published posthumously in 1961, is the product of extensive and detailed engagement with Wittgenstein's Blue Book ('BB') - engagement that Austin seemingly intended his audience to recognize as such. And in Section 3, we will argue that Austin's 1955 William James Lectures, which

\footnotetext{
${ }^{6}$ The classic discussion of this dynamic, albeit applied to poetry rather than philosophy, is Harold Bloom's The Anxiety of Influence; e.g. 'Weaker talents idealize; figures of capable imagination appropriate for themselves. But nothing is got for nothing, and self-appropriation involves the immense anxieties of indebtedness, for what strong maker desires the realization that he has failed to create himself?' (The Anxiety of Influence, 5). To be clear: our point here is not to accuse Austin or the Oxonian originalists of intellectual dishonesty, but merely to point out that authors are often unreliable sources of information about the genesis of their own ideas, and for reasons that are well entrenched in human psychology.
} 
were published posthumously in 1962 as How to Do Things with Words ('HTW'), repeatedly allude to Wittgenstein's Philosophical Investigations (' $\mathrm{PI}$ ') in ways that frame Austin's speech-act theory as a careful and systematic alternative to what Austin took to be Wittgenstein's theoretically profligate views about language use. Both of these points are subtle and easily overlooked, in part because Austin does not cite or explicitly mention Wittgenstein in either work. Austin's citation practices were, shall we say, less than generous. But the textual evidence is compelling when properly contextualized.

Finally, a brief disclaimer. Our argument is not intended to show that Wittgenstein was the only philosopher, or even the single most important one, to influence Austin's thinking about language. There certainly were other influences, some of which are well documented in the literature, but there clearly is not enough space here to compare Wittgenstein's influence to that of all others. Our aim is, rather, to isolate and make the case for one significant source of influence on Austin.

\section{The Blue Book and 'The Meaning of a Word'}

One strain of Oxonian originalism is expressed in the claim that Austin was unfamiliar with Wittgenstein's later work until late in his career - sometime after he had begun to develop his philosophical views on language. According to Isaiah Berlin, for example, so-called Oxford Analysis developed 'without, so far as I can recollect, any conscious reference at the time to Wittgenstein's later doctrines, even though the "Blue Book" was already in circulation in Cambridge, and had, I think, by 1937 or so, arrived in Oxford' (Berlin, Personal Impressions, 11). And Stuart Hampshire claims that, as of 1936-39, Austin 'knew very little of Wittgenstein's later work' (Hampshire, 'J. L. Austin, 1911-1960', 44).

According to various sources, the Blue Book began to circulate within England as early as 1936 and, as Berlin reports, it arrived in Oxford soon thereafter (cf. Monk, Wittgenstein, 336-7). By this time, Austin had become part of a community of philosophers, together with Berlin and Hampshire, whose most accomplished and influential member was A. J. Ayer, and who held regular philosophical discussions in Berlin's rooms. Austin's widow has been reported as saying that it is most likely that he read BB in the 1930s (Sbisà, 'Austin on Meaning and Use', 15n2).

It is therefore a fair conjecture that Austin would have had access to BB as early as 1937. Our first aim in this section is to present what we think is conclusive textual evidence of this conjecture. On the basis of this evidence, we will conclude that Austin's early views on the philosophy of language came together in an atmosphere already thick with late-Wittgensteinian influence, and also that his earliest views on language must be understood as the result of his direct engagement with Wittgenstein's post-Tractatus work. 
On 23 February 1940, Austin presented 'The Meaning of a Word' to the Moral Sciences Club in Cambridge. We have been unable to determine whether Wittgenstein was present at the talk, but he had himself given a lecture in the Club three weeks before. This, however, does not matter much for the present point. It is clear that Austin expected Wittgenstein or his students to be in attendance. The text itself bears testimony to this fact and wears its debt to Wittgenstein on its sleeve.

The first and most glaring piece of evidence of engagement with BB lies in MW's title, and in its opening lines, which list several variations on its title as 'specimens of nonsense' (Austin, Philosophical Papers, 55). It can hardly be a coincidence, and would not have been looked upon as such by those in attendance, that Austin's list consists of 17 variations on the very first sentence of BB:

What is the meaning of a word?

(Wittgenstein, The Blue and Brown Books, 1)

Austin announces that the aim of the first section of his paper is to 'make it clear that the phrase "the meaning of a word" is, in general, if not always, a dangerous nonsense phrase' (Austin, Philosophical Papers, 56). He then introduces that same section as follows:

I begin, then, with some remarks about 'the meaning of a word'. I think many persons now see all or part of what I shall say: but not all do, and there is a tendency to forget it, or to get it slightly wrong. In so far as I am merely flogging the converted, I apologize to them.

(Austin, Philosophical Papers, 56)

Who are 'the converted', who now see all or part of what he has to say, and what exactly caused their conversion? One very plausible explanation of Austin's words here is that he is alluding to Wittgenstein and the readers of BB. The allusion would surely not be lost on the audience. As noted, the manuscript had been circulating at Cambridge for four years by this point, and was well known to students and faculty. In fact, Austin makes many points or arguments in MW which are plausibly seen as reactions to or influenced by particular passages in the $\mathrm{BB}$, five of which we single out for discussion here.

(1) Meaning as use. BB introduces Wittgenstein's well-known idea that the meaning of a word is, in some sense, to be identified with its use. He spells this out, first, by suggesting that we look at the ordinary practice of explaining the meaning of a word to someone: meaning will be, then, what such an explanation explains (Wittgenstein, The Blue and Brown Books, 1). Wittgenstein claims there are two explanations of this sort, 'verbal' and 'ostensive'. He argues, further, that the way in which one learns the meaning of a word provides important clues about what it means (e.g. Wittgenstein, The Blue and Brown Books, 10-11). 
Austin appears to endorse this picture wholesale. Consider these three examples from MW. First, he writes, early in the text:

Suppose that in ordinary life I am asked: 'What is the meaning of the word racy?' There are two sorts of thing I may do in response: I may reply in words, trying to describe what raciness is and what it is not, to give examples of sentences in which one might use the word racy, and of others in which one should not. Let us call this sort of thing 'explaining the syntactics' of the word 'racy' in the English language. On the other hand, I might do what we may call 'demonstrating the semantics' of the word, by getting the questioner to imagine or even actually to experience, situations which we should describe correctly by means of sentences containing the words 'racy' 'raciness', \&c., and again other situations where we should not use these words.

(Philosophical Papers, 57, italics in original)

Here, Austin describes Wittgenstein's own distinction between two sorts of explanations of meaning, but gives them new labels: 'semantic' instead of 'ostensive' and 'syntactic' instead of 'verbal'. He also assumes, quite clearly, that these two 'ordinary-life' ways of explaining the use of a word like 'racy' provide significant clues about its meaning. A little later, Austin argues that traditional philosophical answers to questions of this sort - e.g. that meanings are ideas, concepts, or collections of sense-data - are absolutely hopeless (compare Wittgenstein, The Blue and Brown Books, 17-18). He makes his point by saying that, if he were to give such answers in ordinary life, the questioner, a 'plain man puzzled', would stare at him as at an imbecile. And this, Austin appears to think, is quite sufficient to show that the answers are incorrect (Philosophical Papers, 59).

Secondly, Austin writes that we could not see what it would mean if someone were to say ' $x$ is extended but has no shape'. His argument is as follows:

In ordinary life we never get into a situation where we learn to say that anything is extended but not shaped nor conversely. We have all learned to use, and have used, the words only in cases where it is correct to use both.

(Philosophical Papers, 68, italics added)

This point closely resembles several similar points made by Wittgenstein in BB. To take only one example, when he wonders how one might learn the meaning of 'three feet' by estimating lengths, Wittgenstein asserts that:

[...] we must examine the relation of the process of learning to estimate with the act of estimating. The importance of this examination lies in this, that it applies to the relation between learning the meaning of a word and making use of the word.

(The Blue and Brown Books, 11, italics in original. See also 24, 60, 72)

Thirdly, in MW Austin undertakes to apply Wittgenstein's notion of meaning as use in challenging the positivist idea - expressed by Ayer - of a distinction 
between analytic and synthetic sentences (Austin, Philosophical Papers, §2). He maintains, first, that analyticity cannot be explained in terms of the standard idea that meanings have 'parts' and, second, that the set of all natural language sentences cannot be neatly divided into analytic and synthetic. Here is Austin:

But this is the point: if 'explaining the meaning of a word' is really the complicated sort of affair that we have seen it to be, and if there is really nothing to call 'the meaning of a word' - then phrases like 'part of the meaning of the word $x^{\prime}$ are completely undefined: it is left hanging in the air, we do not know what it means at all.

(Philosophical Papers, 62-3, italics in original)

As we shall see shortly, Austin clearly meant to suggest that there is never any object which we can properly call 'the meaning of a word'. His main point here, however, is that if meaning is determined by ordinary explanations of use, the idea that meanings have parts becomes obscure or even nonsensical.

Furthermore, Austin argues that words and sentences never really 'imply' anything, only using words or asserting something by uttering a sentence can do so. And, thus, talk of analytic 'sentences' is again discredited.' Using Moore's paradox as an example, Austin argues that 'The cat is on the mat, and I do not believe it' is absurd because 'asserting $p$ implies "I (who assert $p$ ) believe $p^{\prime \prime}$, , not because the sentence itself, divorced from its use in assertion, implies this (Philosophical Papers, 64). He goes on to claim that a sentence like 'This $x$ exists', where $x$ is an object of perception, e.g. a noise, cannot possibly fit either the analytic or the synthetic category. It might seem analytic, Austin maintains, since 'This noise exists' appears trivial and its negation absurd. His alternative proposal is again based on the distinction between an expression and its use: "... using the word "this" (not: the word "this") gives it to be understood that the sensum referred to "exists"' (Philosophical Papers, 65, his italics). However, he suggests, the sentence as such cannot be analytic or synthetic.

(2) The 'Augustinian' conception of language. In BB, Wittgenstein repeatedly warns against using proper names as a model for all linguistic expressions. This later becomes associated, in the Investigations, but also in the Brown Book, with a passage from Augustine's Confessions. ${ }^{8}$ On the first page of BB, Wittgenstein writes that '[s]tudying the grammar of the expression "explanation of meaning" [...] will cure you of the temptation to look about you for some object which you might call "the meaning"' (The Blue and Brown

\footnotetext{
${ }^{7}$ Generalizing this point, in his lectures published as Sense and Sensibilia, Austin holds that '[...] there is no kind of sentence which as such is surprising, or doubtful, or certain, or incorrigible, or true' (Sense and Sensibilia, 111).

${ }^{8}$ The Brown Book had also been circulated among philosophers before Austin writes MW, although not as widely as the Blue Book. It is entirely possible that Austin had also read or seen the former (cf. Hacker, Wittgenstein's Place, 86).
} 
Books, 1). When railing against the idea that the meaning of a word is an image in the mind or object correlated with the word, he argues that we make this mistake because 'we are looking at words as though they all were proper names, and we then confuse the bearer of a name with the meaning of the name' (The Blue and Brown Books, 18; also 5, 36, 47).

In MW, Austin takes the same line in a way that is strikingly reminiscent of Wittgenstein's discussion. One is 'tempted to slip back' (Philosophical Papers, 61) into thinking of meaning in terms of 'concepts', 'images', or 'Platonic ideas', Austin says, even when one understands full well that the meaning of a word is determined by 'explaining its syntactics and demonstrating its semantics' (Philosophical Papers, 60). Austin writes:

First, there is the curious belief that all words are names, i.e. in effect proper names, and therefore stand for something or designate it in the way that a proper name does.

(Philosophical Papers, 61, italics in original)

Here and elsewhere, Austin follows Wittgenstein in using the language of temptation or (mental) disease in describing philosophical mistakes (also talking of 'cures' and 'maladies'). Thus, both the point itself and the ways in which it is presented by the two authors are eerily alike.

(3) The bewitchment of words. Among Wittgenstein's most familiar and influential ideas is that ordinary language is systematically misleading. Roughly, he thought that, below the surface of linguistic expressions that all look somewhat similar, there is a broad diversity of function. Overlooking these 'grammatical' distinctions, such as the one between the objective and subjective uses of 'I' and 'my' was, Wittgenstein thought, responsible for a great deal of confusion in philosophy (The Blue and Brown Books, 66). Philosophy itself was even defined in these terms. Thus, in BB, he asserts: 'Philosophy, as we use the word, is a fight against the fascination which forms of expression exert upon us' (The Blue and Brown Books, 27). And, of course, the idea is shot through all of the Investigations, crystallized in an aphorism: 'Philosophy is a struggle against the bewitchment of our understanding by the resources of our language' (Philosophical Investigations, §109).

This way of thinking was, surely, not entirely new at the time, but Austin's wording and framing of the point in MW seems to owe something directly to Wittgenstein. When describing the source of philosophical mistakes, he says that he thinks he can see 'that there are difficulties about our powers of imagination, and about the curious way in which it is enslaved by words' (Philosophical Papers, 67). To illustrate this point, he suggests that the reason why one cannot see what someone could mean by saying ' $x$ is extended but has no shape' is that the meanings of the two nouns are so restricted as to describe and evoke only the ordinary cases. And those cases are, allegedly, 
mutually exclusive. As Austin puts it, '[o]rdinary language blinkers the already feeble imagination' (Philosophical Papers, 68, italics in original). It is surely possible that he is alluding to others, such as Ryle, but Ryle was commonly known to have been profoundly influenced by Wittgenstein ever since they became friends in 1929, publishing a paper called 'Systematically Misleading Expressions' four years later. Describing their first meeting, Ryle says he had already been a 'mystified admirer' of the Tractatus, particularly because of the distinction it makes between sense and nonsense (Ryle, 'Autobiographical', 5). The same consideration applies, just more strongly, if Austin's words are taken as allusions to Wisdom, who was more explicit than most that his writings were heavily indebted to Wittgenstein. One can clearly be influenced by Socrates through the medium of Plato (though no analogy is perfect).

(4) Craving for generality. Wittgenstein announces that instead of giving any kind of general answer to a philosophical question such as 'What are signs?' he would rather 'look closely at particular cases which we should call "operating with signs"' (The Blue and Brown Books, 16). The misguided goal of answering questions about the nature of things in general - as opposed to questions about particular things - arises from philosophers' deep-seated 'craving for generality' and a misplaced desire to emulate the 'method of science' (The Blue and Brown Books, 17-18).

That this point made a lasting impression on Austin is clearly on display in MW:

I can only answer a question of the form 'What is the meaning of " $x$ "?' if " $x$ " is some particular word you are asking about. This supposed general question is really just a spurious question of a type which commonly arises in philosophy.

(Philosophical Papers, 58) $^{9}$

It seems, moreover, that one of Austin's actual motivations in writing MW was to expose an apparent inconsistency in Wittgenstein's thinking. BB itself kicks off with a question - 'What is the meaning of a word?' - that, according to Austin, falls foul of the ban on generalities. In labelling the question a specimen of nonsense, Austin thus finds Wittgenstein wanting by a strict application of his own methodological principles.

(5) Family resemblance. In BB, Wittgenstein says that the craving for generality is partly explained by the misguided tendency to assume that there must be something in common to all entities which are ordinarily subsumed under a single word. He famously proposes that a noun like 'game' really only applies to a family of variously related activities, so different games need not have any

\footnotetext{
${ }^{9}$ This negative claim also plays a leading role in 'Other Minds' and Sense and Sensibilia. Of course, Austin still believed that some measure of generality and theory construction was sensible - the theory of speech acts would not have been possible otherwise.
} 
characteristics in common (The Blue and Brown Books, 17). Relatedly, Wittgenstein claims that although '[...] in general we don't use language according to strict rules', comparing language use to rule-governed activities can be helpful in dissolving philosophical problems (The Blue and Brown Books, 25).

In MW, Austin puts a distinctively Oxonian spin on this idea. He argues 'that it is not in the least true that all the things which I "call by the same (general) name" are in general "similar"' (Philosophical Papers, 69, italics in original). Staying true to his classical education, he uses Aristotle's example of 'healthy' as an illustration, which has a certain core meaning but exhibits considerable variation. Although he does not discuss Wittgenstein's example of 'game', he illustrates the point by appeal to words for two particular games, 'cricket' and 'golf'. ${ }^{10}$

Austin's lecture also includes memorable observations on the lack of strict and comprehensive rules for the use of language. He imagines a cat which, unexpectedly, delivers a philippic. Is it still a cat? Was it never a real cat? Here, Austin says, ordinary language simply breaks down and we are at a loss for words (Philosophical Papers, 67-8). Although Wittgenstein does not use such absurdities to illustrate the point in BB, he does precisely that in $\mathrm{PI}$, §80, where he imagines a chair that disappears and reappears. This remark was actually written in Wittgenstein's notebook in 1936 (see MS $152,79[1])$, so it could possibly have reached Austin by word of mouth, e.g. through Friedrich Waismann or Stuart Hampshire. ${ }^{11}$ Waismann would make much of these kinds of examples when introducing concepts with 'opentexture' in his article 'Verifiability', where he imagines meeting a friend who suddenly evaporates and reappears ('Verifiability', 122). Both Waismann and Hampshire were teaching in Oxford by 1939, and Waismann showed Hampshire the typescript of the book - completed two years earlier - on which he had been working with Wittgenstein for a long time (Hacker, Wittgenstein's Place, 163-4).

Hampshire and Austin began working closely together no later than 1937, when they started meeting regularly with other Oxford philosophers in All Souls. In MW, Austin cites Hampshire's first published article, which he had delivered to the Aristotelian Society in December 1939, just two months before Austin's delivery of MW at Cambridge (Philosophical Papers, 60n1).

\footnotetext{
${ }^{10}$ Nikolay Milkov (A Hundred Years of English Philosophy, 155n10) agrees, and writes that it is 'obvious' that Austin is following Wittgenstein here.

${ }^{11}$ Note that absurdities of this sort are often discussed by Wittgenstein. There is the case of lumps of cheese suddenly growing or shrinking (Philosophical Investigations, §142), houses turning into steam and cattle speaking words (On Certainty, §513). And in Zettel, Wittgenstein essentially makes Austin's point:
}

If you imagine certain facts otherwise, describe them otherwise, than the way they are, then you can no longer imagine the application of certain concepts, because the rules for their application have no analogue in the new circumstances. 
There can be no doubt, after studying his first article, that Hampshire had read and been influenced by BB. For example, Hampshire makes crucial use of the notion of criteria of identity in his argument. He asserts that sentences have clear criteria of identity but that this is not so clear in the case of propositions ('Ideas, Propositions and Signs', 22-3). Although Wittgenstein must have taken this terminology from Frege's Grundlagen (Die Grundlagen der Arithmetik) it seems much more likely that Hampshire picked it up from reading BB (e.g. $55,61)$.

To hammer the point home, however, it can be shown that Hampshire's paper is also influenced by BB in many of the ways listed above. For example, Hampshire speaks of sentences that refer 'to no imaginable situation because our rules of use are what they are,' and states that 'in the ordinary use of language definitions are not so explicitly and thoroughly formulated as to provide for all possible cases' ('Ideas, Propositions and Signs', 16). Later he objects to the craving for generality, saying that the question 'What do all sentences mean as such?' is unanswerable and insignificant ('Ideas, Propositions and Signs', 19). And, like Austin, he repeats Wittgenstein's distinction between 'verbal' and 'ostensive' explanations of meaning, without using those exact labels ('Ideas, Propositions and Signs', 19, also 12-13).

It seems to us that the best explanation of this textual evidence, taken as a whole, is that Austin and Hampshire had both read and engaged seriously with the arguments in BB. Their own ideas are influenced and infused with Wittgenstein's thought on a range of issues. Most probably, they discussed BB thoroughly before writing their lectures. Hampshire's contention that Austin was unfamiliar with Wittgenstein's work at the time must therefore be seen as either disingenuous or based on a lapse of memory. In light of the fact that all of this evidence has been available for decades, we therefore find it remarkable that scholars have persisted in denying that Austin's early work bore Wittgenstein's influence. ${ }^{12}$

\section{How to do things with Wittgenstein}

We are convinced that Austin's earliest work on the philosophy of language was steeped in Wittgenstein's influence. But what about the later work for which Austin is best known? In particular, what about How to do Things with Words (HTW)? Can this founding document of speech-act theory also be dusted for Wittgenstein's fingerprints?

\footnotetext{
${ }^{12}$ Lynd Forguson ('Oxford and the "Epidemic"', 332-3), for example, claims that Austin's first published paper 'Are There A Priori Concepts?' ('Ideas, Propositions and Signs') contains 'no trace' of Wittgenstein's influence, and implies that Wittgenstein must therefore have had very little influence on Austin. It is surprising that neither Forguson nor, apparently, anyone else has considered MW in connection to this question, given that it was delivered at the same stage of his early career. The only exception we know of is Stanley Cavell who, very briefly in a footnote, points out that ('curiously') MW is Austin's most Wittgensteinian piece of writing (Cavell, Must We Mean, 97n2).
} 
There are some reasons to think that Austin's theory of speech acts predated much of his contact with Wittgenstein's published later work, in particular the Philosophical Investigations. In his editorial preface to HTW, J. O. Urmson quotes an unpublished supplemental note, reporting that 'Austin says of the views that underlie these lectures that they "were formed in 1939"' (Austin, How to Do Things, v). Moreover, some of the ideas that eventually made their way into HTW were presented in talks and published work at least as early as 1946 - for example, in Austin's Cambridge lecture on 'Nondescription' and in his 1946 Aristotelian Society paper, 'Other Minds'.

But although the early inspiration that eventually led to the theory of speech acts may have struck as early as the late 1930s, there are good reasons to think Austin's work on speech acts took the form that has become canonical only in the mid-1950s, around the time when Austin prepared his 1955 William James Lectures at Harvard, which were published as HTW, as well as a $1956 \mathrm{BBC}$ radio talk which was later published as 'Performative Utterances' (PU). We think it likely that Austin developed his views about speech acts in stages whose development is mirrored by the structure of HTW. The most memorable and influential concepts of Austin's mature theory - including the idea of a speech act, as well as the distinction between locutionary, illocutionary, and perlocutionary acts - do not make their first appearance until the eighth lecture of HTW. Probably, then, Austin developed those concepts late in the process of writing the 1955 typescript on which HTW is based. He started working on the typescript as early as after the summer of 1952, which is when he began delivering his yearly lectures entitled 'Words and Deeds' at Oxford, and according to Urmson they always covered 'approximately the same ground as the William James Lectures' (Austin, How to Do Things, vi). Since there are unmistakable allusions to Wittgenstein and the Investigations in HTW and PU (see below), it is reasonable to think that Austin developed his speech-act theory partly in response to Wittgenstein's views, which were widely known. The earlier HTW lectures are taken up with various attempts to draw a distinction between performative and constative utterances - a distinction that Austin ultimately abandons at the end of the seventh lecture. ${ }^{13}$ And it is the distinction between performative and constative utterances, rather than the mature theory of speech acts, for which we find evidence in Austin's work from the 1940s.

Austin's surviving prewar writings, including MW (as we saw in \$2), show little sign of his mature views, giving the lie to Austin's claim that his views were in place by 1939. In 'Other Minds' (1946), the only early glimmer of the ideas in HTW is Austin's discussion of the possibility that first-person

\footnotetext{
${ }^{13}$ The same structure is embodied by PU and 'Performatif-Constatif' (1963), which Austin presented in Royaumont in March, 1958.
} 
knowledge ascriptions are performative utterances, and his comparison of them to promises in this regard. The essay contains neither the concept of an illocutionary act nor the doctrine of felicity conditions. It is therefore consistent with what we know that Austin's speech-act theory developed in the late 1940s or early 1950s, and perhaps only after he would read the Investigations after they were published in April or May $1953 .^{14}$

It is important to point out that there are at least two senses of the phrase 'speech-act theory', each of which may be applied to precursors of Austin. In its first, broader sense, the phrase is used to refer to an area of inquiry within the philosophy of language that admits of competing approaches. Speech-act theory, on this conception, is the study of assertions, questions, commands, and other illocutionary acts, whatever their natures turn out to be. The disagreement at the centre of speech-act theory in this sense is the question of what constitutes the performance of an illocutionary act - a question for which there are quite a few answers currently on the table. In its second, narrower sense, 'speech-act theory' names a particular theoretical approach to speech-act theory in the broad sense. This is the tradition of taking illocutionary acts to be 'conventional procedures', defined by the conditions of their felicitous performance - and this is the view defended by Austin himself and later by Searle ('What Is a Speech Act?', Speech Acts). In order to avoid ambiguity, we will use 'speech-act theory' in its broad sense, and we will use 'conventionalism' for Austin's own theoretical approach.

Speech-act theory had been going on, here and there, before Austin popularized the term 'speech act'. In similar passages near the beginning of HTW and PU, Austin makes it clear that his work has precursors, locating his own inquiry within a broader movement away from the idea that language is primarily for making statements. According to Austin, this movement had happened in two stages. Stage one came when some philosophers began to claim that certain putative statements were actually nonsensical, and so were not proper statements at all. Stage two arrived when philosophers began to 'set some limits to the amount of nonsense that we are prepared to admit we talk', and, in turn, began to ask 'whether many apparent pseudo-statements really set out to be "statements" at all' (How to Do Things, 2-3).

The only philosopher Austin cites in connection to each stage is Kant (this in the HTW version of the passage), but this appears to be meant as a bit of coy or ironic misdirection. (Indeed, he leads off his description of these two movements with the phrase, '[b]ut now in recent years...' (HTW, 2).) It is easy to see from Austin's allusions to the verification principle that the perpetrators of stage one count among their ranks the logical positivists. In

\footnotetext{
${ }^{14}$ Thanks to Christian Erbacher for discussion about the publication date. Milkov (A Hundred Years of English Philosophy, 188) writes that PI was published on 1 May.
} 
particular, we should think of A. J. Ayer, who was a foil for much of Austin's work, and whose seminal 1936 monograph, Language, Truth, and Logic, declares all of metaphysics, religion, and ethics to be nonsensical. Austin allusively links his second stage to the early expressivisms of C. L. Stevenson ('The Emotive Meaning', Ethics and Language) and R. M. Hare (The Language of Morals) by saying that "ethical propositions" are perhaps intended, solely or partly, to evince emotion or to prescribe conduct or to influence it in special ways' (Austin, How to Do Things, 2-3).

But it is also natural to interpret Austin's descriptions of the two stages, at least in part, as allusions to the early and late Wittgenstein, respectively. Although the practice of alleging nonsense for philosophical purposes had its Twentieth-Century origin in Russell's theory of types, and Frege's discussion of the concept-object distinction, it first grew into a bludgeon near the end of the Tractatus, where Wittgenstein concludes that all non-scientific statements, including those of ethics, metaphysics, and even his own philosophical views are, strictly speaking, nonsensical and so cannot be expressed. Austin describes the second stage in terms of 'the new slogan - of the "different uses of language"', and this is most likely an allusion to the later Wittgenstein's work and influence (Philosophical Papers, 234). Moreover, Austin illustrates this point by saying that:

many specially perplexing words embedded in apparently descriptive statements do not serve to indicate some specially odd feature of the reality thus reported, but to indicate (not to report) the circumstances in which the statement is made or reservations to which it is subject or the way in which it is to be taken or the like.

(Austin, How to Do Things, 3)

The distinction between reporting and indicating to which Austin here alludes closely resembles distinctions drawn by Wittgenstein - for example, his distinction between subjective and objective uses of the first person. (We will expand on the influence of this idea on Austin below.) Given the fervour with which both phases of Wittgenstein's work had swept the philosophical world by the mid-1950s, Austin could not have but expected sophisticated readers to have understood these passages as allusions to Wittgenstein.

In the very next paragraph of PU, Austin's allusions to Wittgenstein become undeniable:

Certainly there are a great many uses of language. It's rather a pity that people are apt to invoke a new use of language whenever they feel so inclined, to help them out of this, that, or the other well-known philosophical tangle; we need more of a framework in which to discuss these uses of language; and also I think we should not despair too easily and talk, as people are apt to do, about the infinite uses of language. Philosophers will do this when they have listed as many, let us say, as seventeen; but even if there were something like ten thousand uses of language, surely we could list them all in time. This, 
after all, is no larger than the number of species of beetle that entomologists have taken the pains to list.

(Austin, Philosophical Papers, 121)

This passage plainly alludes to $\$ 23$ of $\mathrm{Pl}$, where Wittgenstein declares that 'there are countless different kinds of use of what we call "symbols", "words", "sentences"', before supporting this claim with a list of uses of language. If we individuate the items on this list using semicolons and emdashes (not the only option, but a reasonable one), then Wittgenstein's list has exactly seventeen items.

Austin's conception of his relationship to Wittgenstein in the mid-1950s is further illustrated by an anecdote recounted by George Pitcher, who was a graduate student at Harvard when Austin delivered his William James Lectures. Pitcher reports that, having already resolved to work on themes raised by the Investigations, he was excited by the seemingly related content of Austin's lectures. In this context, Pitcher visited Austin's office, where the following scene unfolded:

In the course of our conversation, I let it be known that I thought words were tools, with manifold uses. Austin said, 'Let's see what Witters has to say about that', and he reached for his copy of the Philosophical Investigations. He read, among others, section 23, where Wittgenstein lists some of the uses of language - giving orders, speculating about an event, play-acting, making a joke, and so on. Austin remarked that these things are all quite different, and can't just be lumped together like that.

(Pitcher, 'Austin', 24)

What did Austin mean by saying that Wittgenstein's different uses of language 'are all quite different, and can't be lumped together'? The answer can be found in a passage from the eighth HTW lecture, in which Austin makes essentially the same point, but then expands on it by pointing out that many 'uses of language' do not count as either illocutionary or perlocutionary acts:

... the expression 'use of language' can cover other matters even more diverse than the illocutionary and perlocutionary acts. For example, we may speak of the 'use of language' for something, e.g. for joking; and we may use 'in' in a way different from the illocutionary 'in', as when we say 'in saying " $p$ " I was joking' or 'acting a part' or 'writing poetry'; or again we may speak of 'a poetical use of language' as distinct from 'the use of language in poetry'. These references to 'use of language' have nothing to do with the illocutionary act.... The normal conditions of reference may be suspended, or no attempt made at a standard perlocutionary act ...

(How to Do Things, 104)

This passage immediately follows Austin's introduction of the distinction between locutionary, illocutionary, and perlocutionary acts, and thus contributes to its initial framing of the central concepts of speech-act theory. Thus, he once again frames his inquiry with an allusion to Wittgenstein, but now with 
an explanation of how his own view - armed with systematic distinctions and stripped of an aversion to positive theorizing - constitutes an improvement over Wittgenstein's unsystematic talk of 'uses of language'. First, the latter talk blurs any distinction between the locutionary, illocutionary, and perlocutionary. For example, one can talk of using a sentence as a warning (illocutionary act) just as well as using a sentence to persuade (perlocutionary act). Secondly, 'use' can go beyond anything covered by the threefold distinction, such as when language is used jokingly or poetically. Thirdly, some speech acts, such as for insinuating or evincing emotion (e.g. 'I swear ... '), are also uses of language while it is less clear whether, or how exactly, they would fit into Austin's classification. Note, also, that at this point Austin has already stated that even if talk of 'meaning' is 'hopelessly ambiguous', switching to 'use' makes us no better off, clearly alluding to Wittgenstein's well-known ideas (How to Do Things, 100).

That Austin repeatedly frames his inquiry into speech acts as an improvement over Wittgenstein's approach to language use is illuminating. These passages strongly suggest that Austin took his subject matter to be the same as Wittgenstein's, even if he thought that Wittgenstein's own approach to that subject matter was lazy and methodologically unsound. Austin's view seems to have been that Wittgenstein's late philosophy of language represented some of the earliest, clumsy steps in the philosophical study of language use. Austin's theory of speech acts represents a more mature, careful, and systematic take on the same topic.

So far, we have suggested that Austin's views about language developed out of an engagement with Wittgenstein and the issues he raised. In short, we think it likely that engagement with Wittgenstein's work helped to shape Austin's conception of speech-act theory, understood in the broad sense as the study of the various things that we do with language.

Can we also find traces of Wittgenstein's influence on Austin's positive, conventionalist approach to speech-act theory? Here our enterprise veers a little into more speculative terrain, but we think that an affirmative answer is at least quite plausible. Specifically, there is a widespread and influential (if not necessarily accurate) reading of the later Wittgenstein's philosophy of language, on which it anticipates Austin's conventionalism in important ways.

Austin's notion of speech acts grew out of his struggle to make a principled distinction between performative and constative utterances. When he realized that no such distinction could be made - because so-called constatives were speech acts in exactly the same sense that performatives were - he traded the performative-constative distinction for the threefold distinction between locutionary, illocutionary, and perlocutionary acts. The very idea of a performative utterance, however, is arguably influenced by Wittgenstein's Blue Book - a point that shows through in Austin's 
earliest appeal to the performative-constative distinction in 'Other Minds' (1946)..$^{15}$

In BB and elsewhere, Wittgenstein argues that to utter a sentence like 'I am in pain' is not to make a statement about anyone in particular or to describe any mental state (The Blue and Brown Books, 67). Rather, it is more like the act of moaning, so that pain is expressed directly in one's behaviour (The Blue and Brown Books, 68-9, 74). 'She is in pain', however, is considered to be very different. Here, Wittgenstein is widely interpreted as deflating the idea that we have incorrigible access to our own mental states; our temptation to assume that we do is explained by the fact that we express pain with firstperson sentences that superficially resemble the third-person sentences we use to describe others' pain. But expressing a mental state like pain in language is just a sophisticated substitute for instinctual pain-behaviour. And that is why, according to him, it makes little sense to raise epistemic doubts in such cases.

Not only is this distinction canvassed in BB, it is also the note that sounds throughout Wisdom's articles on other minds, published in Mind 1940-1943, where Wisdom continually flags his debt to Wittgenstein in footnotes. ${ }^{16}$ Austin's own article 'Other Minds' is explicitly addressed to Wisdom's work and its final 1946 instalment. He even begins with what should likely be taken as a humorous allusion to Wittgenstein and his disciples, by joking that he must be '... one sort of fool to rush over ground so well trodden by the angels' (Philosophical Papers, 77).

Some of Austin's article is taken up with a distinction between first- and third-person uses of psychological verbs. An example to which Austin follows Wittgenstein in devoting considerable attention is 'I know', which, like Wittgenstein, he takes to be used as an expression of assurance or confidence, rather than to report on a state of mind, as in 'she knows'. ${ }^{17}$ But whereas this instance of Austin's distinction appears to be drawn from Wittgenstein, Austin goes on to argue that the distinction between firstand third-person uses of verbs extends beyond psychological examples. Anticipating his later discussions in the early sections of HTW and PU,

\footnotetext{
${ }^{15}$ We are not the first to note the similarity between Wittgenstein's remarks on expressive, non-descriptive uses of first-person statements involving psychological verbs and Austin's performatives (e.g. Pears, The False Prison, 346-7; Dummett, Frege, 332-5). It should be noted, however, that Austin's notion of a performative must also have been influenced by $\mathrm{H}$. A. Prichard's work on promising (see, especially, Prichard, Moral Obligation, ch. 7). This has been pointed out before (Warnock, 'John Langshaw Austin', 5; Hampshire, 'J. L. Austin, 1911-1960', 43-4).

${ }^{16}$ See, for example, Wisdom (Other Minds, 174-5, 208). Berlin identifies Wisdom as one of the earliest indirect routes by which the later Wittgenstein's views reached Austin (Berlin, Personal Impressions, 11-15); see Hacker (Wittgenstein's Place, 95).

${ }^{17}$ See, e.g. Wittgenstein (The Blue and Brown Books, 19-20, 23, 26-7). Later, in On Certainty, he writes: 'We are asking ourselves: what do we do with a statement "I know ... "? For it is not a question of mental processes or mental states. And that is how one must decide whether something is knowledge or not' (On Certainty, §230). Compare Austin (Philosophical Papers, 98-103).
} 
Austin points out, for example, that saying 'I promise' is an act of promising whereas saying 'She promises' is merely to describe such an act and, according to Austin, could not be an act of promising (Philosophical Papers, 98n1). As Pears (The False Prison, 347n34) notes, the two philosophers differ in that Wittgenstein's examples involve instinctual or natural expressive acts, while Austin expands his interest to include conventional or ritualistic acts, including the act of marrying, which would come to be a central example in HTW. This gives us some reason to think that Austin's notion of a performative utterance was conceived of as a precisification or development of Wittgenstein's category of naturally expressive speech. ${ }^{18}$

Later, in Austin's mature speech-act theory, illocutionary acts are considered to be linguistic instances of 'conventional procedures'; to perform one is to behave in a way that conforms to a suite of 'felicity conditions', which are defined by pre-existing social conventions. To christen a ship, for example, just is to utter a certain form of words in certain prescribed circumstances while possessing a certain position of authority and certain mental states, and all of this is a matter of the local customs and laws in whose jurisdiction one falls. For Austin, the project of describing the range of possible illocutionary acts boiled down to classifying them according to their felicity conditions. Generalizations about the nature of illocutionary acts take the form of generalizations about the features of the social conventions that define them (How to Do Things, 14-18).

Conventionalism, a different version of which has been developed by Searle ('What Is a Speech Act?'), stands in contrast to a variety of other theories of the nature of illocutionary acts. Alternatives include theories on which illocutionary acts are individuated in terms of the speaker's intentions (Bach and Harnish, Linguistic Communication and Speech Acts; Grice, Studies in the Way of Words; Schiffer, Meaning; Strawson, 'Intention and Convention in Speech Acts'), their characteristic effects on the shared conversational context (Lewis, 'Scorekeeping in a Language Game'; Portner, 'The Semantics of Imperatives'; Roberts, 'Context in Dynamic Interpretation', 'Information Structure in Discourse'; Stalnaker, 'Assertion'), the kinds of psychological states they express (Bar-On, Speaking My Mind; Green, Self-Expression), the discursive commitments they engender (Brandom, Making It Explicit; MacFarlane, 'What Is Assertion?'), or the epistemic norms that govern them (Williamson, Knowledge and Its Limits). Given this range of options, we can intelligibly ask whether Wittgenstein held any of these views, or early prototypes of them, and, if so, which? Answering this question is difficult for at least two reasons.

\footnotetext{
${ }^{18}$ Note that Gilbert Ryle also described such expressions in The Concept of Mind (1949), calling them 'avowals' (see 101-2, 183-4). It is uncontroversial that Ryle is influenced here by Wittgenstein although, famously, he does not cite anyone at all in that book.
} 
First, much has been made of the idea that Wittgenstein is an anti-theoretical philosopher, and so it may be objected that it does not make sense to read him as putting forward a theory of speech acts. This may be correct when it comes to the project of Wittgenstein exegesis - an issue on which we can remain neutral - but the point is irrelevant to the question at hand. Even if it is ultimately a misreading of Wittgenstein to project theoretical commitments onto him, still, he appears to make many claims about the nature of language and meaning, and many interpreters have attempted to organize these claims into a cohesive view. Our claim is only that it is most plausible to interpret Austin as having drawn on this kind of reading (we argue for this claim below).

Secondly, each of the approaches mentioned above can be seen to be influenced by some parts of Wittgenstein's later work. And, indeed, some proponents of non-conventionalist approaches to speech-act theory explicitly mention Wittgenstein as an inspiration. ${ }^{19}$ This should not be so surprising if Wittgenstein was anti-theoretical in the sense explained. Even if he was, his work was undeniably pregnant with deep pre-theoretical insight, and he seems to have been pulled in the direction of different theories of language at different times in his life. Again, our goal is to argue merely that the protoAustinian reading of Wittgenstein is a popular and tempting one, and may have stood out to Austin himself, not that these other potential readings are incorrect or implausible.

With these caveats in mind, it is clear that (i) PI easily and readily invites a conventionalist interpretation, especially when seen through the prism of BB, (ii) this is still considered to be the most accurate and compelling interpretation by many influential Wittgenstein scholars today and, most importantly perhaps, (iii) this was indeed the considered interpretation of Austin's contemporaries and colleagues.

Take, for example, the influential exegetical work of Baker, Hacker and Glock (e.g. Baker and Hacker, Part I: Essays, Part Il: Exegesis §§1-184; Glock, A Wittgenstein Dictionary, 'Necessity and Language'; Hacker, 'Meaning and Use'). On their view, very roughly, Wittgenstein holds that language is best understood by analogy to games, such as chess. Games are governed by conventional rules that determine the correct use of an item or device that is subject to the conventions. To explain the role or 'meaning' of a chess piece is to explain the rules governing its proper use in the game of chess. Similarly, since the meaning of a word cannot simply be an object - of any sort - to which the word refers, it is better to say that the meaning of a word is determined by its correct use in the language.

\footnotetext{
${ }^{19}$ Wittgenstein can be seen as a precursor to Gricean intentionalism, for example (Unnsteinsson, 'Wittgenstein as a Gricean Intentionalist'). Similarly, Bar-On ('Expression') cites Wittgenstein as holding a precursor to expression-theoretic views. And Sellars ('Some Reflections on Language Games') and Brandom (Making It Explicit) read a version of their own normative functionalisms into his work.
} 
Kathrin Glüer and Åsa Wikforss ('Es braucht die Regel nicht') argue that such an interpretation 'remains stuck in [Wittgenstein's] middle period' (156). That is to say, it overlooks important differences between BB and other writings from the early 1930s on the one hand, and the Investigations on the other, supposing that sentences can simply be plucked from the former to clarify ideas in the latter. This procedure results in a thoroughly conventionalist interpretation, since in his middle period Wittgenstein is more easily seen as a conventionalist. Since Austin had been familiar with BB for many years before reading $\mathrm{PI}$ it is not surprising that he would read the former into the latter in this way, like many others did and continue to do.

Further support derives from the fact that most of Austin's colleagues and contemporaries read Wittgenstein as a conventionalist. Already in January 1954, Peter Strawson published a long critical notice of PI, spelling out a conventionalist interpretation of Wittgenstein's theory of linguistic meaning. Strawson writes that, for the author, the meaning of a word ' ... is a matter of the customary practice of the user' ('Critical Notice', 85), that obeying a rule is to conform to '... an agreed common practice' which sometimes requires the existence of ' ... agreed common criteria' (81). 'Customary practice' is the criterion for correct applications of a rule (80). About a year later, Paul Feyerabend also published a long review, reaching similar conclusions. Wittgenstein, on his view, articulates - but cannot be said to fully endorse a theory according to which ' ... the meaning of a sign is constituted by its use within a certain language-game' ('Wittgenstein's Philosophical Investigations', 476). And language games, on Feyerabend's reading, are customs (475). ${ }^{20}$

Ultimately, then, it is rather easy to imagine how a conventionalist reading may have stuck out to Austin as he was formulating his own version of speech-act theory. For example, if we were to substitute 'social convention' for 'language game', in \$21 of the Investigations, it reads as a straightforwardly conventionalist account of the distinction between reports and orders:

Imagine a language-game in which $A$ asks and $B$ reports the number of slabs or blocks in a pile, or the colours and shapes of the building-stones that are stacked in such-and-such a place. - Such a report might run: 'Five slabs'. Now what is the difference between the report or statement 'Five slabs' and the order 'Five slabs!'? - Well, it is the part which uttering these words plays in the language-game. ${ }^{21}$

For Austin, reports and orders are paradigmatic examples of illocutionary acts, which are 'done as conforming to a convention' (How to Do Things, 105). This

\footnotetext{
${ }^{20}$ Norman Malcolm's ('Wittgenstein's Philosophical Investigations') review is much harder to pin down and is open to both conventionalist and less conventionalist interpretations.

${ }^{21}$ See also, for example, PI, $\S \S 41,199,241-2$. And, in $§ 355$, Wittgenstein writes, simply, that the language of sense impressions, ' ... like any other, rests on convention'.
} 
is what makes them different from perlocutionary acts, wherein a speaker brings about or achieves something in a way that goes beyond the conventional import of what they do. So, given the reading of Wittgenstein that we have summarized, Wittgenstein and Austin agree in broad strokes: what one does in speaking is determined by the conventional rules to which one conforms in speaking; which rules are in effect is a matter of the activity in which one is engaged; the nature of this activity is ultimately a matter of social convention.

To be sure, it is impossible, when discussing HTW, to reach anything like the certainty we feel about Wittgenstein's influence on Austin's early views and writings. If any of Austin's notebooks, student notes, lecture notes or other unpublished material from the late 1940s and early 1950s comes to light, we might be able to stand on firmer ground and have a better grasp of how Austin's ideas developed over time. ${ }^{22}$

However, it is consistent with what we know, and independently plausible, that some of the most consequential ideas in HTW were developed by Austin in response to Wittgenstein's post-Tractatus philosophy of language. Austin clearly believed that Wittgenstein was asking new and important questions. And part of Wittgenstein's apparent answer to these questions - that meaning is use and use is determined by rules or conventions - seems to have provided Austin with a sensible, yet vague, starting point.

\section{Conclusion}

Although the precise timing and details of Wittgenstein's impact on Austin remain unclear, we think it relatively clear that Austin's philosophy of language was infused, at each crucial stage in its development, with Wittgenstein's thought. First, in light of the impact of Wittgenstein's Blue Book on 'The Meaning of a Word', we should conclude that Wittgenstein was among Austin's important early influences. Second, we have presented some reasons to think that Austin's earliest extant use of the performative-constative distinction began as a generalization of Wittgenstein's distinction between expressive and descriptive uses of psychological predicates. Third - although the evidence for this point is less decisive - it is consistent with the currently available evidence that Wittgenstein's later work, including the Philosophical Investigations, shaped Austin's mature work on speech acts - both by framing the questions he aimed to address and by helping to inspire Austin's own, more systematic answers to those questions.

\footnotetext{
${ }^{22}$ The published version of HTW is based on Austin's notes, 'Words and Deeds', the typescript of which is housed at the Bodleian Library in Oxford. In the Appendix, 165, Urmson explains that the manuscript corresponds quite closely to the published text of HTW and, so, it can tell us only about Austin's views as they stood in 1955, providing little or no illumination on how the views developed.
} 


\section{Acknowledgements}

We would like to thank Zed Adams, David Egan, Mark Rowe, Guy Longworth, Eliot Michaelson, Siobhan Chapman, Nat Hansen, Marina Sbisà, and those who attended our talk at the 2016 SSHAP conference in Denver, Colorado, for comments and encouragement. We are grateful to two anonymous reviewers for this journal for helpful comments. We would also like to thank Jim and Mary Otten for hosting us in Denver, where we completed the manuscript on their back deck.

\section{Funding}

The authors acknowledge the support of the Icelandic Centre for Research (163132051) and Elmar acknowledges the support of the Irish Research Council (GOIPD/ 2016/186) while working on parts of this article.

\section{ORCID}

Daniel W. Harris (D) http://orcid.org/0000-0002-4764-3703

Elmar Unnsteinsson (D) http://orcid.org/0000-0001-5333-1784

\section{Bibliography}

Austin, J. 'Other Minds'. Proceedings of the Aristotelian Society, Supplementary Volume, 20 (1946): 148-87.

Austin, J. How to Do Things with Words. Oxford: Clarendon, 1962a.

Austin, J. Sense and Sensibilia. Oxford: Oxford University Press, 1962b.

Austin, J. "Performative-Constative". In Philosophy and Ordinary Language, edited by C.

E. Caton, 22-54. Urbana: University of Illinois Press, 1963.

Austin, J. Philosophical Papers. 3rd ed. Oxford: Clarendon, 1979.

Ayer, A. Language, Truth and Logic. London: Gollancz, 1936.

Bach, K., and R. Harnish. Linguistic Communication and Speech Acts. Cambridge, MA: MIT Press, 1979.

Baker, G., and P. Hacker. Wittgenstein: Understanding and Meaning. Vol. 1. Part I: Essays. 2nd ed. Oxford: Blackwell, 2005a.

Baker, G., and P. Hacker. Wittgenstein: Understanding and Meaning. Vol. 1. Part II: Exegesis $\S \S 1-184$. 2nd ed. Oxford: Blackwell, 2005b.

Bar-On, D. Speaking My Mind: Expression and Self-Knowledge. Oxford: Oxford University Press, 2004.

Bar-On, D. "Expression: Acts, Products, and Meaning". In Meaning Without Representation, edited by S. Gross, N. Tebben, and M. Williams. Oxford: Oxford University Press, 2015.

Berlin, I. Personal Impressions. New York: Viking, 1981.

Berlin, I. Enlightening: Letters 1946-1960. London: Chatto \& Windus, 2009.

Bloom, H. The Anxiety of Influence. Oxford: Oxford University Press, 1973.

Brandom, R. Making It Explicit. Cambridge, MA: Harvard University Press, 1994.

Cavell, S. Must We Mean What We Say? Cambridge, UK: CUP, 1969.

Dummett, M. Frege: Philosophy of Language. 2nd ed. London: Duckworth, 1981.

Feyerabend, P. 'Wittgenstein's Philosophical Investigations'. The Philosophical Review 64 , no. 3 (1955): 449-83. 
Findlay, J. N. 'Wittgenstein's Philosophical Investigations'. Revue Internationale de Philosophie 7, no. 25 (1953): 201-16.

Forguson, L. 'Oxford and the "Epidemic" of Ordinary Language Philosophy'. The Monist 84, no. 3 (2001): 325-45.

Frege, G. Die Grundlagen der Arithmetik: eine logisch-mathematische Untersuchung über den Begriff der Zahl. Breslau: W. Koebner, 1884.

Gellner, E. Words and Things. Boston: Beacon, 1959.

Glock, H.-J. A Wittgenstein Dictionary. Oxford: Blackwell, 1996.

Glock, H.-J. 'Necessity and Language: In Defence of Conventionalism'. Philosophical Investigations 31, no. 1 (2008a): 24-47.

Glock, H.-J. What Is Analytic Philosophy? Cambridge, UK: CUP, 2008b.

Glüer, K., and A. Wikforss. "Es braucht die Regel nicht: Wittgenstein on rules and meaning". In The Later Wittgenstein on Language, edited by D. Whiting, 148-66. New York: Palgrave Macmillan, 2010.

Green, M. S. Self-expression. Oxford: Oxford University Press, 2007.

Grice, P. Studies in the Way of Words. Cambridge, MA: Harvard University Press, 1989.

Hacker, P. M. S. Wittgenstein's Place in Twentieth-Century Analytic Philosophy. Oxford: Blackwell, 1996.

Hacker, P. M. S. "Meaning and Use". In The Later Wittgenstein on Language, edited by D. Whiting, 26-44. New York: Palgrave Macmillan, 2010.

Hampshire, S. 'Ideas, Propositions and Signs'. Proceedings of the Aristotelian Society 40 (1940): 1-26.

Hampshire, S. "J. L. Austin, 1911-1960". In Symposium on J. L. Austin, edited by K. T. Fann, 33-49. London: Routledge, 1969.

Hare, R. M. The Language of Morals. Oxford: Oxford University Press, 1952.

Kemp, G. What Is This Thing Called Philosophy of Language? London: Routledge, 2013.

Lewis, D. 'Scorekeeping in a Language Game'. Journal of Philosophical Logic 8, no. 3 (1979): 339-59.

MacFarlane, J. "What Is Assertion?" In Assertion, edited by H. Cappelen and J. Brown. Oxford: Oxford University Press, 2011.

Malcolm, N. 'Wittgenstein's Philosophical Investigations'. The Philosophical Review 63, no. 4 (1954): 530-59.

Marion, M. 'Oxford Realism: Knowledge and Perception II'. British Journal for the History of Philosophy 8, no. 3 (2000): 485-519.

McGuinness, B., ed. Wittgenstein in Cambridge. Oxford: Blackwell, 2008.

Monk, R. Wittgenstein: The Duty of Genius. London: Penguin, 1991.

Milkov, N. A Hundred Years of English Philosophy. Dordrecht: Springer, 2003.

Pears, D. The False Prison, Vol. 2. Oxford: Oxford University Press, 1988.

Pitcher, G. "Austin: A Personal Memoir." In Essays on J. L. Austin, edited by I. Berlin, 17-30. Oxford: Oxford University Press, 1973.

Portner, P. "The Semantics of Imperatives Within a Theory of Clause-Types." In Proceedings of SALT 14, edited by K. Watanabe and R. Young, 235-252. Ithaca, NY: CLC Publications, 2004.

Prichard, H. A. Moral Obligation. Oxford: Oxford University Press, 1949.

Roberts, C. "Context in Dynamic Interpretation." In The Handbook of Pragmatics, edited by L. Horn and G. Ward, 197-220. Oxford: Blackwell, 2004.

Roberts, C. 'Information Structure in Discourse'. Semantics and Pragmatics 5 (2012): 169.

Ryle, G. The Concept of Mind. London: Hutchinson, 1949. 
Ryle, G. "Autobiographical." In Ryle, edited by O. P. Wood and G. Pitcher, 1-15. New York: Macmillan, 1970.

Sbisà, M. 'Austin on Meaning and Use.' Lodz Papers in Pragmatics 8, no. 1 (2012): 5-16.

Schiffer, S. Meaning. Oxford: Oxford University Press, 1972.

Searle, J. "What Is a Speech Act?" In Philosophy in America, edited by M. Black, 221-39. London: Allen and Unwin, 1965.

Searle, J. Speech Acts. Cambridge, UK: CUP, 1969.

Searle, J. "J. L. Austin." In A Companion to Analytic Philosophy, edited by A. P. Martinich and D. Sosa. Oxford: Oxford University Press, 2001.

Sellars, W. 'Some Reflections on Language Games'. Philosophy of Science 21, no. 3 (1954): 204-28.

Stalnaker, R. "Assertion." In Syntax and Semantics 9, edited by P. Cole, 315-32. New York: Academic Press, 1978.

Stevenson, C. L. 'The Emotive Meaning of Ethical Terms.' Mind 46, no. 181 (1937): 14-31.

Stevenson, C. L. Ethics and Language. New Haven, CT: Yale University Press, 1944.

Strawson, P. 'Critical Notice: Philosophical Investigations by Ludwig Wittgenstein'. Mind; A Quarterly Review of Psychology and Philosophy 63, no. 249 (1954): 70-99.

Strawson, P. 'Intention and Convention in Speech Acts'. The Philosophical Review 73, no. 4 (1964): 439-60.

Unnsteinsson, E. 'Wittgenstein as a Gricean Intentionalist'. British Journal for the History of Philosophy 24, no. 1 (2016): 155-72.

Waismann, F. 'Verifiability'. Proceedings of the Aristotelian Society, Supplementary Volumes 19 (1945): 119-50.

Warnock, G. "John Langshaw Austin, a Biographical Sketch." In Symposium on Austin, edited by K. T. Fann, 3-21. London: Routledge, 1969.

Williamson, T. Knowledge and Its Limits. Oxford: Oxford University Press, 2000.

Wisdom, J. Other Minds. Oxford: Blackwell, 1952.

Wittgenstein, L. Philosophical Investigations. 4th ed. 2009. Oxford: Blackwell, 1953.

Wittgenstein, L. The Blue and Brown Books. 2nd ed. New York: Harper, 1960.

Wittgenstein, L. Zettel. Oxford: Blackwell, 1967.

Wittgenstein, L. On Certainty. Oxford: Blackwell, 1969. 